DOI: 10.46340/eppd.2021.8.1.28

Nataliia Karpinska, PhD in law

ORCID ID: https://orcid.org/0000-0001-9658-3623

Lesya Ukrainka Volyn National University, Lutsk, Ukraine

\title{
INSTITUTIONAL AND FUNCTIONAL SUPPORT OF SANITARY AND PHYTOSANITARY MEASURES APPLICATION IN UKRAINE
}

\author{
Наталія Карпінська, к. ю. н. \\ Волинський національний університет імені Лесі Українки, м. Луцьк, Україна

\section{ІНСТИТУЦІЙНО-ФУНКЦІОНАЛЬНЕ ЗАБЕЗПЕЧЕННЯ ЗАСТОСУВАННЯ САНІТАРНИХ ТА ФІТОСАНІТАРНИХ ЗАХОДІВ В УКРАЇНI}

The study is devoted to the highlighting of the national institutions system, which has an impact on the relationship between the application of sanitary and phytosanitary measures. The relevance of this study necessitates the need to understand the causes and preconditions of the current state of institutional and functional support of sanitary and phytosanitary measures in Ukraine. The study was conducted during the study and combination of analysis of the current state of institutional and functional support of the sanitary and phytosanitary measures application in Ukraine and its retrospective. The functions of the Subcommittee on Management of Sanitary and Phytosanitary Measures are highlighted. In the absence of a special central executive body, the role and importance of the State Service of Ukraine for Food Safety and Consumer Protection is determined. It is investigated how the absence of a profile Ministry of Agriculture of Ukraine affects the institutional and functional support of sanitary and phytosanitary measures - there is a decrease in specialization of agricultural relations, which leads to managerial errors, unjustified rule-making decisions and violations of national interests, business and society. The opinions of scientists on the formation of the State Food and Consumer Service and its effectiveness are analyzed, their own vision of this institution in ensuring public administration in the field of sanitary and phytosanitary measures from the standpoint of a moderate approach is substantiated. The existing projects on liquidation of the State Food and Consumer Service were reviewed and their own position was expressed on the inexpediency of such actions, which will lead to problems with the proper implementation of international legal obligations in this area.

Keywords: sanitary and phytosanitary measures, institutional and functional provision, agricultural legislation, EU requirements, agriculture.

Постановка проблеми. Ускладнення міжнародно-правових зв'язків України все більше ускладнює і систему інституцій, які здійснюють вплив на відносини застосування санітарних та фітосанітарних заходів (далі- СФЗ). Саме тому цілком закономірно, що нині такі відносини регулюються не лише суто національними органами. Це обумовлюється, зокрема, тим, що процес застосування СФЗ багатоаспектний та складний. При цьому не можливо применшити роль належного інституційного забезпечення застосування, регулювання, стандартизації СФЗ. Важливо, що інституційно-функціональна система забезпечення управління та контролю за застосуванням СФЗ поділяється на міжнародний та національний рівні.

На національному рівні інституційно-функціональне забезпечення управління та контролю у сфері застосування СФЗ вимагає поєднання аналізу як сучасного його стану, так і ретроспективи та потребує детального аналізу, який, вбачається, надасть можливість зрозуміти причини та передумови сучасного стану інституційно-функціонального забезпечення СФЗ в нашій державі.

Стан дослідження. Фундаментальною базою для дослідження слугували праці таких науковців як В.Носіка, В. Уркевича, В. Семчика, А. Статівки, В. М. Єрмоленка, Т. Коваленко, А. Годяк, 
А. Духневича, Х. Григор’євої, Ю. Шемшученка, В. Янчука, І. Бураковського, К. Кравчука, В. Мовчана та ін.

Водночас, членство у СОТ, підписання Угоди про асоціацію з СС та необхідність виконання передбачених зобов'язань зумовлюють потребу у дослідженні особливостей розвитку законодавства у сфері санітарних та фітосанітарних заходів, зокрема, дослідження інституційно-функціонального забезпечення застосування санітарних та фітосанітарних заходів у контексті національного законодавства.

Постановка проблеми. Національна інституційно-функціональна система забезпечення СФЗ у сільському господарстві має власні особливості та специфічні риси.

Динамічність управлінської структури. Жоден орган, що входить до сфери регулювання СФЗ в Україні, не функціонував без змін правового становища принаймні кілька років. Перманентні трансформації управлінської структури породжують невизначеність та певний ступінь нестабільності таких відносин. Причини такої динамічності вбачаються і в політичних проблемах, і в мінливих економічних завданнях, i в необхідності виправлення попередньо допущених управлінських помилок тощо. Як дуже вдало писав свого часу В. І. Семчик, характерною рисою органів управління сільським господарством $€$ те, що їх повноваження по регулюванню сільського господарства звужуються під гаслом прав і господарської самостійності підприємців та невтручання держави в господарську діяльність приватних господарських товаровиробників ${ }^{1}$. Тобто численні модифікації управлінської структури обслуговують різні цілі, однак не формують необхідного рівня здорового протекціонізму в сільському господарстві.

Довгий час система органів, що забезпечували управління та контроль щодо застосування СФЗ, була досить розгалуженою. Наприклад, В. С. Кайдашов доходив висновку про те, що загальна система органів контролю за дотриманням законодавства про безпечність та якість сільськогосподарської продукції могла бути класифікована таким чином: (1) органи, що здійснюють контроль за виробництвом та обігом продукції тваринництва (ветеринарна адміністрація); (2) органи, що здійснюють контроль за виробництвом та обігом продукції рослинництва (органи фітосанітарного контролю); (3) органи, що забезпечують санітарне та епідемічне благополуччя споживачів сільськогосподарської продукції (санітарно-епідеміологічна служба); (4) органи, що здійснюють контроль за дотриманням прав споживачів ${ }^{2}$. Така розпорошеність органів, що мають справу із СФЗ, досить часто критикувалася науковцями.

Тенденції до євроінтеграції спонукали пошук нових оптимальних моделей інституційної моделі. Зокрема, останніми роками відбувалося об'єднання та централізація функцій у цій сфері, особливо контрольно-наглядових. При цьому, як вказують науковці, за умов загальної нестабільності системи органів виконавчої влади у державі підсистема контрольно-наглядових органів $\epsilon$ ще більш хиткою та такою, що перебуває під деструктивним впливом політичної кон'юнктури. Відтак загалом правильний i, більш того, як вбачається, безальтернативний шлях до модернізації цієї сфери публічного управління, приведення іiі до європейських та світових стандартів, піддається ризикам, з одного боку, надмірної лібералізації, з іншого ж, безкінечного пошуку моделей побудови системи органів публічної адміністрації з відповідними функціями та повноваженнями ${ }^{3}$. Підвищений динамізм управлінської структури не йде на користь належному виконанню покладених на публічне управління завдань у сфері СФЗ.

Ми не зупинятимемося на аналізі ролі та функціонального значення численних інспекційних органів, що існували та змінювали одне одного протягом незалежності України. Однак, на наш погляд, варто більш детально дослідити специфіку органу, який було втрачено у процесі трансформації управлінської структури, а саме ветеринарної міліції. Законом України «Про ветеринарну медицину» у попередніх редакціях передбачалося, що формування

\footnotetext{
${ }^{1}$ Семчик, В. И. (2003). Проблемы адаптации аграрного законодательства Украины к законодательству Европейского Союза. Проблемы гармонизачии законодательства Украины и стран Европьl, 411-423. ${ }^{2}$ Кайдашов, В. С. (2012) Організаційно-правові засади безпечності та якості сільськогосподарської продукції: автореферат дисертаиії на здобуття наукового ступеня кандидата юридичних наук. Харків : Юридична академія імені Ярослава Мудрого, 3-20.

${ }^{3}$ Бондар, О. Г. (2019). Контрольно-наглядова діяльність як гарантія реалізації та захисту екологічних прав: деякі проблеми інституційного забезпечення. Еколого-правовий статус людини і громадянина: ретроспективний та перспективний погляди: матеріали Міжнарод. наук. практ. конф. (Киї, 31 травня 2019 року). Київ, 13-18.
} 
і функціонування підрозділів ветеринарної міліції відбувається задля гарантування санітарної та епідеміологічної безпеки, яка є складовою національних інтересів. Слід зазначити, що цей орган має власну історію. Так, 11 червня 1966 року наказом Міністра охорони громадського порядку Української РСР № 268 було створено відомчу міліцію для забезпечення карантинних і ветеринарносанітарних заходів у боротьбі з епізоотіями. Саме з цього часу починають своє функціонування підрозділи ветеринарної міліції. Завдання підрозділів ветеринарної міліції, які покладалися на неї у часи незалежності, дещо відрізнялися від колишніх завдань. Відповідно до п. 2 «Положення про підрозділи ветеринарної міліції з проведення карантинних ветеринарних заходів», затвердженого постановою Кабінету Міністрів України № 395 від 29 березня 2002 року, вказані підрозділи створювалися для надання практичної допомоги державним органам ветеринарної медицини в організації та здійсненні контролю і нагляду за виконанням вимог ветеринарно-санітарних заходів щодо профілактики, локалізації та ліквідації карантинних хвороб тварин. Це ж було відображено і в Законі України «Про ветеринарну медицину». Задля виконання таких завдань підрозділи ветеринарної міліції були наділені повноваженнями в основному неюрисдикційного характеру, які реалізувалися у межах здійснення контролю та нагляду за виконанням фізичними та юридичними особами ветеринарно-санітарних вимог. Наприклад, у Харківській області у 2006 році працівниками відділу ветеринарної міліції було перевірено 40 сільськогосподарських підприємств, у результаті чого було виявлено 20 порушень ветеринарно-санітарних вимог, а у 2007 році кількість перевірених сільськогосподарських підприємств склала вже 123 об'єкти і було виявлено 73 порушення ветеринарно-санітарних вимог. У 2007 році було перевірено 68 ринків. Внаслідок перевірок виявлено 357 порушень ветеринарно-санітарних вимог, серед яких 336 вчинених громадянами та 21 посадовими особами ${ }^{1}$.

Необхідність утворення спеціалізованого органу обумовлювалася тим, що розповсюдження особливо небезпечних інфекційних карантинних хвороб тварин, як правило, характеризується напруженістю епізоотичного процесу. Тому від оперативності реагування та проведення ветеринарно-санітарних заходів щодо недопущення, локалізації та ліквідації збудників цих хвороб залежить подальша епізоотична безпека держави ${ }^{2}$. Саме 3 огляду на об'єктивні особливості СФЗ ветеринарній міліції був притаманний централізм. Доктрина виходить 3 того, що централізм як позитивний показник організації - дискусійний для багатьох галузей через ризик віддалення від місцевих проблем. Проте коли йдеться про інспекцію та санітарну поліцію, він $є$ гарантом незалежності та ефективності в державному масштабі ${ }^{3}$.

Узагалі, якщо інспекційні та інші контрольно-наглядові органи, які функціонували на теренах України протягом останніх тридцяти років, у цілому мали подібні риси, то органи ветеринарної міліції суттєво відрізнялися своїм проміжним положенням - «напівінспекція» та «напівміліція». Втрата цього органу в процесі реформування суттєво відбилася на інституційному забезпеченні СФЗ в Україні.

Отже, динамізм управлінської структури здебільшого проявляється у двох напрямах: а) інституційному (утворення, реорганізація, ліквідація органів); та б) функціональному (поява повноважень та функцій, їх зміна, відміна, передання іншим суб'єктам тощо).

Хронічна проблема узгодження повноважень. Критичним питанням, що завжди викликало теоретичні дискусії та практичні проблеми, слід визнати розмиті рамки компетенції органів та дублювання деяких повноважень. При цьому спірні ситуації виникали на усіх етапах: і під час утворення нових органів (формування кола їх повноважень), і протягом їх функціонування, і навіть після їх ліквідації. Розподіл повноважень завжди був чутливим питанням в українських реаліях.

Яскравим прикладом цієї характерної ознаки можна вказати історію з узгодженням підготовленого пакету законопроектів у сфері санітарних, ветеринарних і фітосанітарних заходів. Так, $з$ причини недосягнення узгодженості щодо розмежування повноважень між органами виконавчої влади, які здійснюють державний контроль і нагляд за безпекою харчових продуктів

\footnotetext{
${ }^{1}$ Василенко, В. М. (2009). Адміністративно-правовий статус працівників ветеринарної міліції: автореферат дисертаиії на здобуття наукового ступеня кандидата юридичних наук. Харків: ХНУВС, 3-19.

${ }^{2}$ Горбунова, О. Ю. (2009). Правовий статус працівників ветеринарної міліції з проведення карантинних ветеринарних заходів: автореферат дисертації на здобуття наукового ступеня кандидата юридичних наук. Київ : Нац. ун-т біоресурсів і природокористування України, 3-18.

${ }^{3}$ Довгань, В. І. (2011). Зарубіжний досвід державного управління ветеринарною справою. Держава та регіони. Серія: Державне управління, 27-30.
} 
тваринного походження, а саме Міністерством охорони здоров'я та Міністерством аграрної політики, ці законопроекти кілька місяців не вносилися на розгляд, що свого часу затягувало процесу вступу до $\mathrm{COT}^{1}$.

Проблема розмежування відомчої компетенції традиційно досить болісна в Україні. Наприклад, кілька років тому в Україні контролем безпечності харчових продуктів займалися чотири органи: Державна санітарно-епідеміологічна служба, Державна ветеринарна та фітосанітарна служба, Державна інспекція сільського господарства, Державна екологічна інспекція. Проте жоден із цих органів не гарантував безпечності продукту загалом, оскільки вони контролювали лише деякі ділянки виробництва, не забезпечуючи при цьому контроль на всій ділянці «від лану - до столу» ${ }^{2}$, а у спірних моментах - намагалися «перекинути» відповідальність на інший орган.

Вiдсутність профільного міністерства. В Україні за період незалежності кілька разів змінювалися назва, функції та компетенція органів управління сільським господарством. Було Міністерство сільського господарства і продовольства України. Міністерство агропромислового комплексу України було перейменовано в Міністерство аграрної політики України ${ }^{3}$. Уперше за тридцять років незалежності у 2019 році аграрний сектор залишився без профільного міністерства. Відтепер проблемами сільського господарства опікуватиметься Мінекономіки. Метою об'єднання Міністерства економічного розвитку i торгівлі з Мінагрополітики було досягнення певного синергетичного ефекту в результаті об'єднання функцій державного управління у різних сферах суспільного життя. Водночас важливою складовою реалізації державної аграрної політики є розвиток сільських територій, охорона навколишнього природного середовища та забезпечення раціонального природокористування у сільському господарстві. Водночас існування окремого центрального органу державної виконавчої влади, відповідального за формування та реалізацію державної аграрної політики, $\epsilon$, на думку Н. О. Багай, необхідною умовою належного державного регулювання сільського господарства, підвищення ефективності та конкурентоспроможності аграрного сектора, забезпечення комплексного розвитку сільських територій та розв'язання соціальних проблем на селі ${ }^{4}$ Це добре усвідомлюють й інші країни. Наприклад, одним із найбільш активних американських органів державного регулювання в аграрній сфері $є$ Міністерство сільського господарства США. Створене понад 100 років тому воно спочатку займалося саме питаннями СФЗ: організацією та управлінням у сфері боротьби з хворобами та шкідниками рослин, захворюваннями тварин, у сфері насінництва та племінної справи. Натепер міністерство значно розширило сферу своєї діяльності та компетенцію. Воно займається не тільки питаннями виробництва сільськогосподарської продукції, але й регулюванням цін, діяльності ринку, експорту сільськогосподарської продукції, закупок 5

Яким чином відсутність профільного аграрного міністерства впливає на інституційнофункціональне забезпечення СФЗ? Насправді вплив неоднозначний. 3 одного боку, відсутність аграрного міністерства знижує спеціалізованість регулювання аграрних відносин та прямує до уніфікації такого регулювання у межах загального управління економікою. Однак саме СФЗ є тією сферою, в якій пересікаються бізнес, інтереси держави та екологічні проблеми - усі ці аспекти мають враховуватися. Проте в умовах ліквідації профільного міністерства ця специфічність втрачається, що призводить до управлінських помилок, необгрунтованих нормотворчих рішень та порушення національних інтересів, інтересів бізнесу і суспільства. 3 іншого боку, за умов відсутності спеціального центрального органу виконавчої влади змінюється роль та значення Держпродспоживслужби. Наразі вона виконує не лише контрольні та сервісні функції, безпосередньо взаємодіючи із агробізнесом та забезпечуючи його належний супровід - вона перетворилася на єдиний спеціалізований орган державної влади, що за своїми повноваженнями здатен враховувати сільськогосподарські особливості та транслювати потреби аграрного сектору іншим органам влади;

\footnotetext{
1 Лахно, С. (2005). Стратегія та перешкоди на шляху вступу України до СОТ. Міжнародна економічна політика, 103-125.

2 Лисак, М. А. (2016). Угода про асоціацію України з СС та стан торгівлі продовольчими товарами. Економіка АПК, 10, 66-72.

${ }^{3}$ Семчик, В. И. (2003). Проблемы адаптации аграрного законодательства Украины к законодательству Европейского Союза. Проблемы гармонизаџии законодательства Украины и стран Европь, 411-423.

${ }^{4}$ Багай, Н. О. (2020). Державне регулювання сільського господарства: окремі питання. Актуальні правові проблеми земельних, аграрних та екологічних відносин в умовах сучасної земельної реформи: матер. наук.практ. конф. (Харків, 22 травня 2020 року). Харків, 20-23.

${ }^{5}$ Клюкин, Б. Д.(1972). США: правовое регулирование сельского хозяйства. Москва,128-133.
} 
Євроінтеграиійна модель побудови інституиійно-функиіонального забезпечення СФЗ. Існуюча в Україні строкатість контрольно-наглядових органів, розпорошення та дублювання функцій між численними інспекціями не відповідало євроінтеграційним прагненням України. У зв'язку з цим була поставлена амбітна мета - створити на внутрішньому ринку України систему контролю за безпекою продуктів харчування, яка б відповідала європейській. Це довгострокова перспектива, яка вимагатиме значних зусиль як із погляду гармонізації нормативного поля, так і практичного запровадження нових норм державними органами, а також підприємствами ${ }^{1}$. Насправді, певні кроки у напрям централізації повноважень у сфері СФЗ відбувалися давно. Так, до 2010 року контрольно-наглядова діяльність у сільському господарстві характеризувалася розгалуженою системою державних інспекційних органів. Разом з тим, спроби утворити при Мінагрополітики єдиний контрольно-інспекційний орган датуються ще 2006 роком, коли уряд постановою від 25.05.2006 року створив Генеральну державну сільськогосподарську інспекцію на базі Державної інспекції з контролю якості сільськогосподарської продукції та моніторингу іiї ринку та Державної служби з охорони прав на сорти рослин. Однак втілити цю ідею не вдалося. У вересні цю постанову було скасовано. У 2006 році Генсільгоспоінспекція проіснувала лише на папері ${ }^{2}$. Законодавець все ж не полишав надії закріпити європейський досвід у законодавстві України щодо створення єдиного інспекційного органу в сільському господарстві. Ключовим кроком стало прийняття Закон «Про внесення змін до Закону «Про основні засади державного нагляду (контролю) у сфері господарської діяльності». Указані зміни передбачали існування тільки одного органу державного контролю та нагляду. Отже, ідея створення єдиної сільськогосподарської інспекції була законодавчо закріплена, лишалося втілити ії в життя. У 2010 році була створена Державна інспекція сільського господарства України, яка поєднувала контрольно-наглядові та сервісні функції ${ }^{3}$. Попри наявні проблеми у нормативно-правовому забезпеченні контрольно-наглядової та сервісної діяльності Держсільгоспінспекції, на наше переконання, утворення цього органу забезпечило створення єдиної системи контрольноінспекційних органів в аграрному секторі економіки, дозволило посилити результативність контролю за діяльністю відповідних суб'єктів, виключити дублювання функцій контролюючих органів, більш ефективно проводити загальнодержавну політику в АПК, направлену на забезпечення продовольчої безпеки країни, досягнення необхідних державі та суспільству соціальних, економічних та екологічних позитивних результатів ${ }^{4}$. Це надзвичайно важливо, оскільки контрольно-наглядова діяльність у сільському господарстві - це спрямована на забезпечення законності і правопорядку в сфері виробництва сільськогосподарської продукції однорідна діяльність уповноважених органів публічної адміністрації, а також суб'єктів громадського контролю щодо своєчасного виявлення проблем, створення умов для їх вирішення та усунення конфліктів між владними і підлеглими структурами, що здійснюється за допомогою спеціальних правових засобів ${ }^{5}$.

Загалом, державний контроль за змістом та характером спрямований забезпечити повну та необхідну обізнаність уповноважених органів щодо функціонування кожної із галузей сільського господарства з метою перевірки цієї діяльності на відповідність законодавству України. Державний контроль, як засіб державного регулювання є одним із головних чинників визначення ролі держави у забезпеченні безпечності та якості сільськогосподарської продукції шляхом реалізації заходів державного контролю ${ }^{6}$.

\footnotetext{
${ }^{1}$ Лисак, М. А. (2016). Угода про асоціацію України з СС та стан торгівлі продовольчими товарами. Економіка АПК, 10, 66-72.

2 Бондар, О. Г. (2013). Роль Держсільгоспінспекції України у розвитку державно-приватного партнерства у сфері АПК. Актуальні правові проблеми публічно-приватного партнерства у сфері аграрних, земельних, екологічних та космічних відносин: матеріали Міжнарод. наук.-практ. конф. (Київ, 22 листопада 2013 року). Київ, 56-59.

${ }^{3}$ Бондар, О. Г. (2013). Роль Держсільгоспінспекції України у розвитку державно-приватного партнерства у сфері АПК. Актуальні правові проблеми публічно-приватного партнерства у сфері аграрних, земельних, екологічних та космічних відносин: матеріали Міжнарод. наук.-практ. конф. (Київ, 22 листопада 2013 року). Київ, 56-59.

${ }^{4}$ Бондар, О. Г. (2013). Актуальні проблеми нормативного забезпечення діяльності Держсільгоспінспеції України. Сучасні науково-практичні проблеми екологічного, земельного та аграрного права: зб. тез «круглого столу» (Харків, 6 грудня 2013 року). Харків, 90-93.

${ }^{5}$ Бондар, О. Г. (2015). Контрольно-наглядова діяльність у сільському господарстві України: аграрно-правовий аспект: автореферат дисертації на здобуття наукового ступеня кандидата юридичних наук. Київ, 1-38.

6 Яцков, С. М., Павлюченко, Ю. М. (2019). Роль держави у забезпеченні безпечності та якості сільськогосподарської продукції. Журнал студентського наукового товариства, 37-41.
} 
Однак централізація контрольно-наглядових функцій на рівні Держсільгоспінспекції теж не задовольняла потреб євроінтеграційного етапу. I тому у 20.09.2015 року набрали чинності більшість положень Закону України «Про внесення змін до деяких законодавчих актів України щодо харчових продуктів». Він був ухвалений з метою адаптації законодавства України до ЄС у цій сфері та передбачає впровадження в Україні моделі європейської системи безпеки. Положення закону суттєво зменшують кількість адміністративних процедур, державного контролю та скасовують дозвільні процедури, яких не існує в СС. Важливим результатом цього Закону є утворення Держпродспоживслужби ${ }^{1}$.

Слід зазначити, що іiі утворення відбувалося досить складно, оскільки процес ліквідації Державної інспекції сільського господарства розтягнувся де-факто на роки ${ }^{2}$. Це потягнуло формування певного «сірого» періоду, коли старий орган ліквідовувався, а новий народжувався. Під час такого проміжного періоду було зафіксовано порушення, які прямо обумовлювалися суттєвим зниженням контролю за якістю та безпечністю сільськогосподарської продукції. Так, наприклад, В. М. Срмоленко проаналізував ситуацію у 2016 році, коли значні обсяги експортованої продовольчої пшениці відправлялися за кордон під виглядом фуражної, однак одразу після перетину митного кордону це зерно оплачувалося за цінами продовольчої пшениці. Такі операції спричинили передусім недоотримання значного обсягу бюджетних надходжень у вигляді податків. Як прозорливо відмічає науковець, насамперед, виникнення такої ситуації криється у недосконалості державного контролю за оцінкою якості сільськогосподарської продукції, адже саме діяльність контролюючих держави при здійсненні експортно-імпортних операцій має бути індикатором відповідності пропонованої продукції задекларованим якісним показникам ${ }^{3}$.

Отже, Держпродспоживслужба, об'єднавши повноваження окремих контрольно-наглядових органів у сфері СФЗ (Держветфітослужби, Держсанепідслужби), стала втіленням інституційнофункціональної підготовки України до реалізації євроінтеграційних вимог у сфері застосування СФЗ.

Утворення іiі складної внутрішньої структури зайняло тривалий час. Постановою Кабінету Міністрів України від 10 вересня 2014 року № 442 «Про оптимізацію системи центральних органів виконавчої влади» було закріплено іiі утворення ${ }^{4}$. Постановою Кабінету Міністрів України від 02 вересня 2015 року № 667 затверджено Положення про Держпродспоживслужбу․․ Територіальні органи Держпродспоживслужби утворені постановою Кабінету Міністрів України від 16 грудня 2015 року № $1092^{6}$. Відповідно до розпорядження Кабінету Міністрів України від 6 квітня 2016 року № 260-р «Питання Державної служби з питань безпечності харчових продуктів та захисту споживачів» Держпродспоживслужба офіційно розпочала роботу і приступила до виконання функційㄱ.

Оцінки цього кроку в літературі діаметрально протилежні. Думки учених з приводу утворення Держпродспоживслужби та іiі ефективності можна згрупувати та представити у вигляді трьох основних підходів:

а) критичний. Зокрема, висловлюються думки про те, що упродовж 2015 - 2017 років, коли в Україні відбулося реформування системи державних органів шляхом ліквідації Держветфітослужби

\footnotetext{
${ }^{1}$ Власенко, Ю. Л. (2016). До питання про правове забезпечення екологічної безпеки при виробництві, контролю якості та обігу дієтичних добавок (колишніх БАДів). Конституційні засади аграрного, земельного та екологічного права: 20 років розвитку: матер. «круглого столу» (Київ, 27 травня 2016 року). Київ, $320-323$. 2 Бондар, О. Г. (2016). До питання про інституційне забезпечення контрольно-наглядової діяльності в поземельній сфері у контексті сталого розвитку України. Теоретичні та практичні аспекти реалізаџії екологічного, земельного, аграрного права в умовах сталого розвитку України: матер. «круглого столу» (Харків, 2 грудня 2016 року). Харків, 71-74.

${ }^{3}$ Срмоленко, В. М. (2016). Сучасний стан нормативного забезпечення державного контролю за якістю сільськогосподарської продукції. Перше зібрання фахівців споріднених кафедр з обговорення актуальних наукових проблем та методики викладання аграрного, земельного, екологічного та природоресурсного права у вищих навчальних закладах Украйни: матер. зібрання (м. Одеса, 9-10 вересня 2016 року). Одеса: Юридична література, 22-25.

${ }^{4}$ Постанова про оптимізацію системи цуентральних органів виконавчої влади, 2014 (Кабінет Міністрів України). Урядовий кур’єр. 2014. № 169.

${ }^{5}$ Постанова про затвердження Положення про Державну службу Украӥни з питань безпечності харчових продуктів та захисту споживачів, 2015 (Кабінет Міністрів України). Урядовий кур'єр. 2015. № 168.

${ }^{6}$ Постанова про утворення територіальних органів Державної служби з питань безпечності харчових продуктів та захисту споживачів, 2015 (Кабінет Міністрів України). Урядовий кур’єр. 2016. № 4.

7 Розпорядження про питання Державної служби з питань безпечності харчових продуктів та захисту споживачів, 2016 (Кабінет Міністрів України). Урядовий кур’єр. 2016. № 81.
} 
та iii територіальних органів і створення Держпродспоживслужби України, проведення реорганізаційних заходів призвело до погіршення епізоотичної ситуації щодо сказу, АЧС, сальмонельозу, про що свідчить реєстрація спалахів даних гостроінфекційних хвороб тварин на території України протягом 2015 - 2018 років. Це справляє негативний вплив на навколишнє середовище, призводить до значних економічних втрат у тваринництві та погіршення експортного потенціалу держави, підвищує ризик виникнення хвороб, що є спільними для людей і тварин, а також свідчить про незадовільний стан вирішення завдань держави в галузі ветеринарної медицини за напрямом забезпечення захисту здоров'я тварин ${ }^{1}$. В. А. Поліщук пише про те, що сьогодні важко давати оцінку проведеній реорганізації органів державної влади у сфері забезпечення якості та безпечності продуктів харчування, проте можна спрогнозувати, що об'єднання в одне відомство різних функцій ветеринарного, санітарного, фіто-санітарного контролю, не можна вважати виправданим, тому що система і структура органів влади до об'єднання була більш дієвою з точки зору здійснення державного регулювання відносин у сфері сільськогосподарського (промислового) садівництва, зокрема, забезпечення доступу до ринку продукції садівництва, експорту сільськогосподарської продукції, забезпечення фіто-санітарного контролю тощоㅇ․

б) позитивний. Представники цього підходу вітають утворення Держпродспоживслужбй

в) поміркований. Певна група науковців досить стримано аналізує діяльність Держпродспоживслужби. Наприклад, Саркісова говорить про те, що реформа національної системи забезпечення якості та безпеки продуктів харчування та державного контролю у цій сфері поступово завершується. Проведена реформа мала за мету вирішити такі проблеми як недостатній рівень безпечності продуктів харчування за одночасного контролю декількома контролюючими органами одного і того ж оператора харчового ринку, невизначеність показників безпечності харчових продуктів, дублювання функцій і відсутність координації дій різних державних органів, залучених до системи контролю безпечності харчових продуктів тощо. Після 4 років перехідного періоду та 3 років мораторію на перевірки, Держпродспоживслужба (новий орган, який зібрав діючі служби з контролю, у т.ч. фітосанітарного та санітарно-епідеміологічного) отримала можливість розпочати перевіряти операторів ринку харчової продукції, більшість 3 яких мала перейти на систему аналізу небезпечних факторів та контролю у критичних точках (НАССР). Перші результати реалізації функції контролю представляють науковий інтерес ${ }^{4}$.

Ми схильні оцінювати Державпродспоживслужбу та їі значення у забезпеченні публічного управління у сфері СФЗ з позицій поміркованого підходу. Проте, на нашу думку, ліквідація Мінагрополітики та продовольства України стала тим суттєвим фактором, що докорінно змінив ситуацію, і відтепер роль Держпродспоживслужби значно посилилася. Однак слід наголосити, що це не гарантує ій безпроблемне існування та спокійне функціонування. Складна доля контрольнонаглядових органів у сфері сільського господарства вже стала предметом цікавих досліджень. Досить влучно зазначає О. Г. Бондар: «складається враження, що саме слово «інспекція» має апріорі крамольний відтінок, від якого всіляко намагаються відійти. У чомусь подібна ситуація має місце з Державною службою України з питань безпечності харчових продуктів та захисту прав споживачів, але ж Держпродспоживслужба поряд із реалізацією широкого спектра контрольно-наглядових повноважень все ж таки надає різноманітні адмінпослуги» 5 .

Останні тенденції полягають у полеміці щодо доцільності існування Держпродспоживслужби як окремого органу. Прибічники реформаційного підходу переконують у тому, що інституційна система забезпечення контролю за застосуванням СФ3 має бути змінена, а саме:

\footnotetext{
${ }^{1}$ Дідок, Ю. В. (2018). Реформування системи державних органів ветеринарної медицини в Україні: соціологічний вимір. Вісник НАДУ. Серія “Державне управління”, 137-142.

2 Поліщук, В. А. (2016). Правове регулювання сільськогосподарського садівництва в Україні: дисертація на здобуття наукового ступеня кандидата юридичних наук. Київ, 3-126.

3 Туніцька, Ю. М. (2018). Національна митно-тарифна та нетарифна політика за умов євроінтеграції. Економіка і суспільство, 74-84.

${ }^{4}$ Саркісова, Т. (2019). Проблеми правової регламентації системи контролю в сфері екобезпеки продуктів харчування. Еколого-правовий статус людини і громадянина: ретроспективний та перспективний погляди: матеріали Міжнарод. наук. практ. конф. (Київ, 31 травня 2019 року). Київ, 305-308.

${ }^{5}$ Бондар, О. Г. (2019). Контрольно-наглядова діяльність як гарантія реалізації та захисту екологічних прав: деякі проблеми інституційного забезпечення. Еколого-правовий статус людини і громадянина: ретроспективний та перспективний погляди: матеріали Міжнарод. наук. практ. конф. (Київ, 31 травня 2019 року). Київ, 13-18.
} 
Держпродспоживслужба має бути ліквідована, а іï функції та повноваження варто поділити між Міністерством розвитку економіки, торгівлі та сільського господарства та Міністерством охорони здоров'я. Такі пропозиції надзвичайно шкідливі. 3 точи зору забезпечення належної участі держави у публічному управлінні СФЗ у сільському господарстві Мінекономіки не здатне повноцінно замінити спеціалізований орган, яким $є$ Держпродспоживслужба. Особливо небезпечними виглядають пропозиції щодо розподілу матеріально-технічної служби, відповідно до якого лабораторії та інші подібні установи мають відійти до компетенції МОЗ. Реалізація таких проектів здатна нанести важкий та непоправний удар по інституційно-функціональній системі забезпечення СФЗ в Україні. Це неминуче негативно відобразиться на безпосередніх відносинах застосування СФЗ у країні, а також потягне за собою проблеми із належним виконанням міжнародно-правових зобов'язань у цій сфері. Передусім, це потягне негативну реакцію $\mathrm{CC}$, адже ліквідація Держпродспоживслужби стане суттєвим регресом у процесі реалізації Угоди про асоціацію.

Слід зазначити, що ЄС досить пильно слідкує за ходом виконання Угоди про асоціацію. Це забезпечується зокрема й інституційними можливостями. Наразі в Україні існують форми для моніторингу та висвітлення прогресу у виконанні згаданих зобов'язань. Перш за все сформовано систему двосторонніх органів Україна - ЄС, яка включає різні формати зустрічей, наприклад, підкомітет з питань СФ $3^{1}$, на аналізі якого ми дещо зупинимося.

3 метою покращення взаємозв'язку та співробітництва між Сторонами з питань СФЗ сторони (Україна та СС), підписавши Угоду, домовилися про створення Підкомітету з управління СФЗ. При цьому, основними функціями Підкомітету є: 1) контроль за впровадженням положень Глави 4 Угоди про асоціацію «Санітарні та фітосанітарні заходи» та вивчення всіх питань, які можуть виникнути у зв'язку з впровадженням, а також розгляд усіх питань, що стосуються цієї Глави; 2) перегляд та внесення змін до відповідних додатків до зазначеної вище Глави, а також вироблення рекомендації для інших органів відповідно до положень Угоди про асоціацію. Будь-які рішення, рекомендації, звіти або інші дії Підкомітету або будь-якої групи, що створена Підкомітетом, що пов'язані з отриманням дозволів на імпорт, обміну інформацією, дотриманням вимог прозорості, визнанням регіоналізації, еквівалентністю заходів тощо, мають прийматись Сторонами на основі консенсусу².

Так, 16 травня 2017 року в Києві відбулося перше засідання Підкомітету з управління СФ3 Комітету Асоціації Україна - $\mathrm{CC}$ у торговельному складі під головуванням Голови Держпродспоживслужби та начальника відділу двосторонніх міжнародних відносин Генерального Директорату з питань охорони здоров'я та безпечності харчових продуктів Свропейської Комісії (DG «SANTE»). У ході засідання, організованого Держпродспоживслужбою у співпраці з Урядовим офісом з питань європейської та євроатлантичної інтеграції Секретаріату Кабінету Міністрів України, сторони схвалили рішення Підкомітету з управління СФЗ стосовно затвердження Правил процедур та обговорили актуальні питання двостороннього співробітництва між Україною та ЄС у сфері СФЗ та визначили пріоритети ефективної взаємодії у зазначених питаннях. Особливо актуалізується необхідність співпраці Підкомітету з міжнародними організаціями в галузі санітарного та фітосанітарного захисту, особливо з Комісією «Кодекс Аліментаріус», ВООЗТ та Секретаріатом МКЗР. Встановлення механізмів та процедур щодо сприяння торгівлі вимагає в тому числі створення підконтрольних державі структур для забезпечення його практичного застосування, оптимального втілення та настання реальних позитивних наслідків у сфері торгівлі на міжнародному ринку для кожного учасника відповідних господарських відносин ${ }^{3}$.

Висновки та перспективи подальших досліджень. Таким чином, національній інституційнофункціональній системі забезпечення СФЗ у сільському господарстві характерні власні особливості та специфічні риси, зокрема: динамічність управлінської структури, хронічна проблема узгодження

\footnotetext{
${ }^{1}$ Хоменко, О. О. (2017). Виконання зобов'язань у аграрній сфері в рамках Угоди про асоціацію між Україною та СС. Сучасний стан та перспективи розвитку екологічного, земельного й аграрного права в умовах євроінтеграції: матеріали «круглого столу» (Харків, 8 грудня 2017 року). Харків, 104-105.

2 Угода про асоціацію між Україною, з однієї сторони, та Європейським Союзом, Свропейським співтовариством з атомної енергії і їхніми державами-членами, з іншої сторони, 2014 (Україна, Свропейський Союз).

Офіціийний вісник Украӥни. 2014. № 75, 1. Стор. 83. Ст. 2125.

${ }^{3}$ Боснюк-Григор'єва, Ю. (2017). Україна на шляху до європейських стандартів у сфері санітарних та фітосанітарних заходів: що зроблено та які виклики слід подолати. Історико-правовий часопис, 2 (10). 170175 .
} 
повноважень, відсутність профільного міністерства, євроінтеграційна модель побудови інституційнофункціонального забезпечення СФЗ.

Державний контроль, загалом, за змістом та характером спрямований забезпечити повну та необхідну обізнаність уповноважених органів щодо функціонування кожної із галузей сільського господарства з метою перевірки цієї діяльності на відповідність законодавству України.

Держпродспоживслужба, утворення складної внутрішньої структури якої зайняло тривалий час, об'єднавши повноваження окремих контрольно-наглядових органів у сфері СФЗ (Держветфітослужби, Держсанепідслужби), на сучасному етапі $\epsilon$ втіленням інституційнофункціональної підготовки України до реалізації євроінтеграційних вимог у сфері застосування СФЗ.

Реалізація розглянутих у статті проектів щодо ліквідації Держпродспоживслужби здатна нанести важкий та непоправний удар по інституційно-функціональній системі забезпечення СФЗ в Україні. Це неминуче негативно відобразиться на безпосередніх відносинах застосування СФЗ у країні, а також потягне за собою проблеми із належним виконанням міжнародно-правових зобов'язань у цій сфері. Передусім, це потягне негативну реакцію $\mathrm{CC}$, адже ліквідація Держпродспоживслужби стане суттєвим регресом у процесі реалізації Угоди про асоціацію.

\section{References:}

1. Semchik, V. I. (2003). Problemy adaptacii agrarnogo zakonodatel'stva Ukrainy k zakonodatel'stvu Evropejskogo Sojuza. Problemy garmonizacii zakonodatel'stva Ukrainy i stran Evropy [Problems of adaptation of the agrarian legislation of Ukraine to the legislation of the European Union. Problems of harmonization of the legislation of Ukraine and the countries of Europe], 411-423. [in Ukrainian].

2. Kaidashov, V. S. (2012) Orhanizatsiino-pravovi zasady bezpechnosti ta yakosti silskohospodarskoi produktsii [Organizational and legal principles of safety and quality of agricultural products]: avtoreferat dysertatsii na zdobuttia naukovoho stupenia kandydata yurydychnykh nauk [abstract of the dissertation on completion of a scientific degree of the doctor of legal scientific]. Kharkiv: Yurydychna akademiia imeni Yaroslava Mudroho, 3-20. [ in Ukrainian].

3. Bondar, O. H. (2019). Kontrolno-nahliadova diialnist yak harantiia realizatsii ta zakhystu ekolohichnykh prav: deiaki problemy instytutsiinoho zabezpechennia [Control and supervision activities as a guarantee of realization and protection of environmental rights: some problems of institutional support] Ekoloho-pravovyi status liudyny i hromadianyna: retrospektyvnyi ta perspektyvnyi pohliady: materialy Mizhnarod. nauk. prakt. konf. (Kyiv, 31 travnia 2019 roku) [Ecological and legal status of man and citizen: retrospective and perspective views: materials International. Science. practice. conf. (Kyiv, May 31, 2019)], 13-18. [ in Ukrainian].

4. Vasylenko, V. M. (2009). Administratyvno-pravovyi status pratsivnykiv veterynarnoi militsii [Administrative and legal status of veterinary police officers]: avtoreferat dysertatsii na zdobuttia naukovoho stupenia kandydata yurydychnykh nauk [abstract of the dissertation on completion of a scientific degree of the doctor of legal scientific]. Kharkiv: KhNUVS, 3-19. [in Ukrainian].

5. Horbunova, O. Yu. (2009). Pravovyi status pratsivnykiv veterynarnoi militsii z provedennia karantynnykh veterynarnykh zakhodiv [Legal status of veterinary police officers for quarantine veterinary measures]: avtoreferat dysertatsii na zdobuttia naukovoho stupenia kandydata yurydychnykh nauk [abstract of the dissertation on completion of a scientific degree of the doctor of legal scientific]. Kyiv: Nats. un-t bioresursiv i pryrodokorystuvannia Ukrainy, 3-18. [ in Ukrainian].

6. Dovhan, V. I. (2011). Zarubizhnyi dosvid derzhavnoho upravlinnia veterynarnoiu spravoiu [Foreign experience of state management of veterinary affairs]. Derzhava ta rehiony. Seriia: Derzhavne upravlinnia [State and regions. Series: Public Administration], 27-30. [in Ukrainian].

7. Lakhno, S. (2005). Stratehiia ta pereshkody na shliakhu vstupu Ukrainy do SOT [Strategy and obstacles to Ukraine's accession to the WTO]. Mizhnarodna ekonomichna polityka [International economic policy], 103-125. [in Ukrainian].

8. Lysak, M. A. (2016). Uhoda pro asotsiatsiiu Ukrainy z YeS ta stan torhivli prodovolchymy tovaramy [Agreement on the Association of Ukraine with the EU and the state of trade in food products]. Ekonomika APK [Economics of agro-industrial complex], 10, 66-72. [in Ukrainian].

9. Bahai, N. O. (2020). Derzhavne rehuliuvannia silskoho hospodarstva: okremi pytannia [State regulation of agriculture: some issues]. Aktualni pravovi problemy zemelnykh, ahrarnykh ta ekolohichnykh vidnosyn $v$ umovakh suchasnoi zemelnoi reformy: mater. nauk.-prakt. konf. (Kharkiv, 22 travnia 2020 roku) [Actual legal problems of land, agrarian and ecological relations in the conditions of modern land reform: mater. scientificpractical conf. (Kharkiv, May 22, 2020)], 20-23. [in Ukrainian].

10. Kliukyn, B. D. (1972). SShA: pravovoe rehulyrovanye selskoho khoziaistva [USA: legal regulation of agriculture]. Moscow,128-133. [in Russia].

11. Bondar, O. H. (2013). Rol Derzhsilhospinspektsii Ukrainy u rozvytku derzhavno-pryvatnoho partnerstva u sferi APK [The role of the State Agricultural Inspectorate of Ukraine in the development of public-private partnership 
in the field of agriculture]. Aktualni pravovi problemy publichno-pryvatnoho partnerstva u sferi ahrarnykh, zemelnykh, ekolohichnykh ta kosmichnykh vidnosyn: materialy Mizhnarod. nauk.-prakt. konf. (Kyiv, 22 lystopada $2013 \mathrm{roku}$ ) [Current legal issues of public-private partnership in the field of agricultural, land, environmental and space relations: materials International. scientific-practical conf. (Kyiv, November 22, 2013)], 56-59. [in Ukrainian].

12. Bondar, O. H. (2013). Aktualni problemy normatyvnoho zabezpechennia diialnosti Derzhsilhospinspetsii Ukrainy [Actual problems of normative support of activity of the State Agricultural Inspection of Ukraine]. Suchasni naukovo-praktychni problemy ekolohichnoho, zemelnoho ta ahrarnoho prava: zb. tez «kruhloho stolu» (Kharkiv, 6 hrudnia 2013 roku) [Modern scientific and practical problems of environmental, land and agricultural law: Coll. abstracts of the round table (Kharkiv, December 6, 2013)]. Kharkiv, 90-93. [in Ukrainian].

13. Yatskov, S. M., Pavliuchenko, Yu. M. (2019). Rol derzhavy u zabezpechenni bezpechnosti ta yakosti silskohospodarskoi produktsii [The role of the state in ensuring the safety and quality of agricultural products]. Zhurnal studentskoho naukovoho tovarystva [Journal of the Student Scientific Society], 37-41. [in Ukrainian].

14. Vlasenko, Yu. L. (2016). Do pytannia pro pravove zabezpechennia ekolohichnoi bezpeky pry vyrobnytstvi, kontroliu yakosti ta obihu diietychnykh dobavok (kolyshnikh BADiv) [On the issue of legal provision of environmental safety in the production, quality control and circulation of dietary supplements (former dietary supplements)]. Konstytutsiini zasady ahrarnoho, zemelnoho ta ekolohichnoho prava: 20 rokiv rozvytku: mater. «kruhloho stolu» (Kyiv, 27 travnia 2016 roku) [Constitutional principles of agrarian, land and ecological law: 20 years of development: mater. Round table (Kyiv, May 27, 2016)], 320-323. [in Ukrainian].

15. Bondar, O. H. (2016). Do pytannia pro instytutsiine zabezpechennia kontrolno-nahliadovoi diialnosti v pozemelnii sferi u konteksti staloho rozvytku Ukrainy [On the issue of institutional support of control and supervision activities in the land sphere in the context of sustainable development of Ukraine]. Teoretychni ta praktychni aspekty realizatsii ekolohichnoho, zemelnoho, ahrarnoho prava v umovakh staloho rozvytku Ukrainy: mater. «kruhloho stolu» (Kharkiv, 2 hrudnia 2016 roku) [Theoretical and practical aspects of realization of ecological, land, agrarian law in the conditions of sustainable development of Ukraine: mater. Round table (Kharkiv, December 2, 2016)], Kharkiv, 71-74. [in Ukrainian].

16. Yermolenko, V. M. (2016). Suchasnyi stan normatyvnoho zabezpechennia derzhavnoho kontroliu za yakistiu silskohospodarskoi produktsii [The current state of regulatory support for state control over the quality of agricultural products]. Pershe zibrannia fakhivtsiv sporidnenykh kafedr z obhovorennia aktualnykh naukovykh problem ta metodyky vykladannia ahrarnoho, zemelnoho, ekolohichnoho ta pryrodoresursnoho prava u vyshchykh navchalnykh zakladakh Ukrainy : mater. zibrannia (m. Odesa, 9-10 veresnia 2016 roku) [The first meeting of specialists of related departments to discuss current scientific issues and methods of teaching agricultural, land, environmental and natural resources rights in higher educational institutions of Ukraine: mater. meeting (Odessa, September 9-10, 2016)]. Odessa: Yurydychna literatura, 22-25. [in Ukrainian].

17. Postanova pro optymizatsiyu systemy tsentralnykh orhaniv vykonavchoyi vlady, 2014 (Kabinet Ministriv Ukrayiny) [Resolution on optimization of the system of central executive bodies, 2014 (Cabinet of Ministers of Ukraine)]. Uryadovyj kuryer [Government courier]. 2014. № 169. [in Ukrainian].

18. Postanova pro zatverdzhennya Polozhennya pro Derzhavnu sluzhbu Ukrayiny z pytan bezpechnosti kharchovykh produktiv ta zakhystu spozhyvachiv, 2015 (Kabinet Ministriv Ukrayiny) [Resolution on approval of the Regulation on the Civil Service of Ukraine for Food Safety and Consumer Protection, 2015 (Cabinet of Ministers of Ukraine)]. Uryadovyj kuryer [Government courier]. 2015. № 168. [in Ukrainian].

19. Postanova pro utvorennya terytorialnykh orhaniv Derzhavnoyi sluzhby z pytan bezpechnosti kharchovykh produktiv ta zakhystu spozhyvachiv, 2015 (Kabinet Ministriv Ukrayiny) [Resolution on the establishment of territorial bodies of the State Service for Food Safety and Consumer Protection, 2015 (Cabinet of Ministers of Ukraine)]. Uryadovyj kuryer [Government courier]. 2016. № 4. [in Ukrainian].

20. Rozporyadzhennya pro pytannya Derzhavnoyi sluzhby z pytan bezpechnosti kharchovykh produktiv ta zakhystu spozhyvachiv, 2016 (Kabinet Ministriv Ukrayiny) [Order on the State Service for Food Safety and Consumer Protection, 2016 (Cabinet of Ministers of Ukraine)] Uryadovyj kuryer [Government courier]. 2016. № 81. [in Ukrainian].

21. Didok, Yu. V. (2018). Reformuvannia systemy derzhavnykh orhaniv veterynarnoi medytsyny v Ukraini: sotsiolohichnyi vymir [Reforming the system of state bodies of veterinary medicine in Ukraine: a sociological dimension]. Visnyk NADU. Seriia "Derzhavne upravlinnia" [Bulletin of the National Academy of Public Administration. Public Administration Series], 137-142. [in Ukrainian].

22. Polishchuk, V. A. (2016). Pravove rehuliuvannia silskohospodarskoho sadivnytstva v Ukraini [Legal regulation of agricultural horticulture in Ukraine]: dysertatsiia na zdobuttia naukovoho stupenia kandydata yurydychnykh nauk [dissertation on completion of a scientific degree of the doctor of legal scientific]. Kyiv, 3-126.

[in Ukrainian].

23. Tunitska, Yu. M. (2018). Natsionalna mytno-taryfna ta netaryfna polityka za umov yevrointehratsii [National customs-tariff and non-tariff policy in the context of European integration]. Ekonomika i suspilstvo [Economy and society].74-84. [in Ukrainian].

24. Sarkisova, T. (2019). Problemy pravovoi rehlamentatsii systemy kontroliu v sferi ekobezpeky produktiv kharchuvannia [Problems of legal regulation of the control system in the field of food safety.]. Ekoloho-pravovyi 
status liudyny i hromadianyna: retrospektyvnyi ta perspektyvnyi pohliady: materialy Mizhnarod. nauk. prakt. konf. (Kyiv, 31 travnia 2019 roku) [Ecological and legal status of man and citizen: retrospective and perspective views: materials International. Science. practice. conf. (Kyiv, May 31, 2019)]. Kyiv, 305-308. [in Ukrainian].

25. Khomenko, O. O.(2017). Vykonannia zoboviazan u ahrarnii sferi v ramkakh Uhody pro asotsiatsiiu mizh Ukrainoiu ta YeS [Fulfillment of obligations in the agricultural sphere under the Association Agreement between Ukraine and the EU]. Suchasnyi stan ta perspektyvy rozvytku ekolohichnoho, zemelnoho y ahrarnoho prava $v$ umovakh yevrointehratsii: materialy «kruhloho stolu» (Kharkiv, 8 hrudnia 2017 roku) [Current state and prospects of development of ecological, land and agrarian law in the conditions of European integration: materials of the round table (Kharkiv, December 8, 2017)], Kharkiv, 104-105. [in Ukrainian].

26. Uhoda pro asotsiatsiyu mizh Ukrayinoyu, z odniyeyi storony, ta Yevropeyskym Soyuzom, Yevropeyskym spivtovarystvom z atomnoyi enerhiyi i yikhnimy derzhavamy-chlenamy, z inshoyi storony, 2014 (Ukrayina, Yevropeyskyy Soyuz) [Association Agreement between Ukraine, of the one part, and the European Union, the European Atomic Energy Community and their Member States, of the other part, 2014 (Ukraine, European Union)]. Ofitsiynyy visnyk [Official Bulletin of Ukraine]. 2014. № 75, 1. Стор. 83. Ст. 2125. [in Ukrainian].

27. Bosniuk-Hryhorieva, Yu. (2017). Ukraina na shliakhu do yevropeiskykh standartiv u sferi sanitarnykh ta fitosanitarnykh zakhodiv: shcho zrobleno ta yaki vyklyky slid podolaty [Ukraine on the way to European standards in the field of sanitary and phytosanitary measures: what has been done and what challenges need to be overcome]. Istoryko-pravovyi chasopys [Historical and legal journal], 2 (10), 170-175. [in Ukrainian]. 